\title{
Revalidating Saving-Investment Comovement in Nigeria: Surprises, Stylized Facts and Explanations
}

\author{
Enemona Joseph¹, Olatunji Abdul Shobande² \\ ${ }^{1}$ Department of Economics, Faculty of Social Sciences, Caleb University, Lagos, Nigeria \\ ${ }^{2}$ Department of Economics, Faculty of Social Sciences, University of Lagos, Lagos, Nigeria \\ Email: joseph_enemona@yahoo.com, olatunji.shobande@yahoo.com
}

How to cite this paper: Joseph, E. and Shobande, O.A. (2018) Revalidating Saving-Investment Comovement in Nigeria: Surprises, Stylized Facts and Explanations. Theoretical Economics Letters, 8, 3594-3610. https://doi.org/10.4236/tel.2018.815221

Received: November 8, 2018

Accepted: December 10, 2018

Published: December 13, 2018

Copyright (c) 2018 by authors and Scientific Research Publishing Inc. This work is licensed under the Creative Commons Attribution International License (CC BY 4.0).

http://creativecommons.org/licenses/by/4.0/

\section{(c) () Open Access}

\begin{abstract}
Numerous studies have attempted to examine the relationship between savings and investment without a consensus conclusion. Interestingly, there have been profound findings, arguments and scholarly contributions on the subject by different authors, researchers and scholars from most first class institutions around the world. To further heighten the argument around the subject, Feldstein-Horioka in his hypothesis, after running many regression, suggests that saving-investment co-movement under perfect capital mobility remains a puzzle. This paper therefore proposes a reconciliation model to revalidate the co-movement between savings and investment using the dataset sourced from the Central Bank of Nigeria (CBN) Statistical Bulletin between 1981 and 2017. The approach employed followed the Autoregressive Distributed Lag (ARDL) and Granger Causality that presumed economic variables reactions are not instantaneous and effects require a feedback mechanism delay for some period. The results suggest the existence of strong positive correlation between national savings and business investment, proposing that policies/initiatives to increasing the domestic resource mobilization through national saving are crucial for stimulating rate of investment in Nigeria.
\end{abstract}

\section{Keywords}

Saving, Investment, Economic Growth, Nigeria

\section{Introduction}

Researchers, financial analyst and policy makers have been able to empirically establish the fact that savings and investment are inevitable ingredients for economic growth. They have however, not been able to empirically provide the 
explanation to justifies the equality of these variables at equilibrium. Importantly, the equality of savings and investment has been the cause of debate and controversy and, perhaps created puzzle since the ancient time. Several theoretical propositions have been made and laurel credited to various scholars who have made contributions to the development of concepts aimed at resolving the puzzle around the two subjects. Despite efforts being made, reconciling the equality of the two concepts at equilibrium has led to more divergence in view rather than convergence [1]-[12]. The main source of confusion arose from the failure of critics to recognize that while savings and investment are always equal, they are not necessarily so in equilibrium. At the early stage, the proponents of classical economics are of the opinion that the existence of fully employed economy can only occur where savings and investment are equal. The classical economists also argued that investors would always invest all savings. This group of economists further blamed inequality between savings and investment on the interest rate transmission mechanism and argued that the only way to reconcile this inequality would be by using monetary toolkits to stimulate the economy, if full employment must be realized [13]-[23].

In contrast, Keynes [24] disagrees with the classical view that equality between savings and investment is brought about through the mechanism of interest rate. According to Keynes, it is change in income, which brings the two to equality, rather than the rate of interest. Keynes further refutes the classical view that savings and investment are equal at the full employment level arguing that full employment is a rare phenomenon. As such, savings and investment equality can only occur at less than employment [24] [25] [26]. Beyond this controversy, the potential of savings and investment as drivers of economic growth are well established in existing literature. A common pointer among the existing literature confirmed the possibility of capital accumulation and saving mobilization to expand production frontier which is never in doubt [1]-[6].

In Nigeria, the performance of savings, investment and economic growth has not been impressive in recent times. Possible factors responsible for this weak relationship can be attributed to policy inconsistencies, high lending rates, low income capacity and disparity between the bank and unbanked population combine with limited bank branches [27] [28]. There have been efforts by the monetary authority to reconcile the gap between savings and investment through credit policies such as enhancement of credit availability, reduction of cost and improvement of access to credit to influence private investment as well as stimulate the growth of the real sector [27].

Interestingly, the $\mathrm{CBN}$ has continued to persuade banks to pay greater attention to the unbanked population with a view to extending financial services and mobilize savings on one hand, while prescribing aggregate and sectorial allocation of their loans and advances to enhance attainment of long term sustainable growth. While this approach gives priority to sector-lending target and encourage flow of credit to underdeveloped sectors, it has failed to attract savings to the banking sectors; this undermines the flow of credits to financially underserved 
segment within the economy [27] [29] [30]. As it were, these policies/initiatives had good foundation but lack good execution and monitoring framework. For instance, most of the small scale businesses lack access to capital to expand their businesses, while relatively few who have access to finance complained that loan disbursement by Deposit Money Banks (DMBs) have constraint their businesses into meaningful investment [31] [32]. Excuses by lending banks showed that credit is curtailed or delayed because of the rising risk of defaults in loan payment, which have severe implication on stability role of the monetary authorities [33].

Evidently, knowing the degree of capital mobility as well as how savings mobilization can enhance the level of investment is crucial for growth recovery potential, which is the preoccupation of this study. Consequently, this paper makes three important contributions. First, it appreciates the dynamic relationship between domestic savings and investment in Nigeria using the Autoregressive Distributed Lag (ARDL) to check the feedback mechanism among the fundamentals and re-examined their long run relationships. Second, it examines the cyclical and short run relationship among the variables considered. Third, it beams light on major obstacles to domestic investment potential vis-à-vis macroeconomic indicators. The outcome of this study is expected to serve as policy ingredient to number of audiences ranging from policy makers to investors, and the academia alike who may find the study useful and strategic for boosting private investment in Nigeria.

The rest of the paper is organized as follows: Section 2 focuses on review of related literature, while Section 3 presents the theoretical framework and methodology. Section 4 presents statistical inference and econometrics analysis. The paper concludes with relevant policy strategies in Section 5.

\section{Review of Related Literature}

This section is not intended to conduct a full scale review of previous empirical studies on the relationship between savings, investment and economic growth; it selectively undertook the review of selected works considered central to the study.

To start with, several studies have attempted to reconcile the question of whether or not savings hinges on the level of investment using cross country evidence. For instance, in the United State, Levy [43] examined the linkage between investment and savings comovement and capital mobility. The study contributed to literature in three ways. First, the author constructed annual series of gross domestic investment and national savings between 1897 and 1949 using historical component analysis. It compared the qualitative and quantitative properties of the newly constructed series with the properties of four alternative series constructed with the Bureau of Economic Analysis, the Commerce Department, Kuznets and Kendrick. Second, the study re-examined the long run properties of the series by combining the newly constructed data with the $\mathrm{Bu}$ - 
reau of Economic Analysis between 1929 and 1989. Third, the author examined the short run as well as cyclical relationship between savings and investment. The results of the study confirmed strong relationship between savings and investment during the period.

In Botswana, Jagadesh [34] examined the impact of savings and economic growth between 1980 and 2013 using ARDL framework complemented by Ordinary Lease Square (DOLS) approach. The results of the study confirmed that savings, gross capital formation, inflation, export, labour force and economic growth were key determinants of economic growth in Botswana during the period reviewed. In 2006, Chakrabarti [35] re-examined the linkage between savings and investment using a multivariate heterogeneous panel cointegration analysis with annual data for 126 countries between 1960 and 2000. The study found a significant and robust positive association between Gross Domestic Product (GDP) and ratio of national saving to GDP during the period. In India, Verma [36] used Autoregressive Distributed Lag (ARDL), bound testing approach to analyse the long run relationship between gross domestic savings, gross domestic investment and economic growth between 1951 and 2004. The results confirmed the existence of long run relationship with exception of economic growth during the period.

In Turkey, Kaya [37] investigated the effect of domestic savings-investment nexus using Autoregressive Distributed Lag (ARDL), bound testing procedure. The results indicated the existence of structural weakness in the relationship which is consistent with the earlier studies documented by Feldstein and Horioka [38]. Similarly, in Malaysia, Tang and Lean [39] applied Rolling Window Bound testing to empirically investigate the relationship between savings and investment between 1960 and 2007. Their results confirmed existence of cointegration among the variables considered.

In Tunisia, Adebole and Dahalan [40] examined the relationship between savings and investment between 1970 and 2009 using ARDL and Granger Causality test. Their results confirmed the existence of long run relationship between savings and investment fundamentals. In Nigeria, Nasiru and Usman [41] studied the connection between savings and investment between 1980 and 2011 using ARDL bound testing approach. The results of their study confirmed existence of long run relationship among the variables considered. In Namibia, Ayetuoma and Musilika [42] investigated the causal relationship between aggregate savings and aggregate investment between 1995 and 2011. Their study confirmed that savings played a crucial role in financing capital formation during the period reviewed.

A cursory look at the works/studies reviewed points at three key messages: First, existence of divergent empirical outcomes, suggesting the level of inconclusiveness on the link between savings and investment debate. Second, the methodology deficiency and measurement challenges are observed in the reviewed studies. Third, majority of the studies do not provide the theoretical basis of 
their analysis. This study is therefore timely as it provides forum for resolving the aforementioned issues.

\section{Theoretical Groundwork \& Methodology}

\subsection{Theoretical Groundwork}

The theoretical foundation is based on the Keynesian theory that advocates for equality of investment and savings at equilibrium level of national income complimented with the financial liberation hypothesis put forth by Mckinnon [25] and Shaw [26], which postulated that financial liberation has potential of inducing high savings that can help to channel surplus fund to the need of the deficit unit, which in turn has potential of stimulating investment [24] [25] [26] [43]. The justification of this theoretical consideration is based on the fact that their studies are intuitively appealing and provide ground breaking approach to access the correlation between savings and investment in Nigeria.

\subsection{Analytical Framework}

Following Levy [43] and Coakley et al. [44] who earlier showed the possibility of an economy intertemporal budget constraint to be balanced, suggesting that zero frequency coherence and gain of savings and investment will equal one.

We assume that the time series of domestic investment and national saving are non-stationary at level. That is $I_{t} \sim I(I)$, and $S_{t} \sim I(I)$.

Thus,

$$
\begin{gathered}
I_{t}=I_{t-1}+\mu_{t} \\
S_{t}=S_{t-1}+\vartheta_{t}
\end{gathered}
$$

where

$$
u_{t} \sim I(0) \text { and } \vartheta_{t} \sim I(0)
$$

We assumed that investment and savings are cointegrated which means that the process have a common stochastic trend.

Let

$$
\left[\begin{array}{l}
I_{t} \\
S_{t}
\end{array}\right]=\left[\begin{array}{l}
1 \\
1
\end{array}\right] T+\left[\begin{array}{l}
i_{t} \\
S_{t}
\end{array}\right]
$$

Where $T_{t}$ is common stochastic trend with property $(1-L) T_{t}=z_{t}$, $z_{t} \sim i i d\left(0, \sigma^{2}\right), i_{t} \sim I(0), s_{t} \sim I(0)$.

Applying a difference operator to yield a bivariate stationary process, we have,

$$
\left[\begin{array}{c}
(1-L) I_{t} \\
(1-L) S_{t}
\end{array}\right]=\left[\begin{array}{l}
1 \\
1
\end{array}\right] z_{t}+\left[\begin{array}{c}
(1-L) i_{t} \\
(1-L) s_{t}
\end{array}\right],
$$

With spectral matrix

$$
f(\omega)=\left[\begin{array}{cc}
f_{\Delta I} & f_{\Delta I, \Delta s} \\
f_{\Delta s, \Delta I} & f_{\Delta s}
\end{array}\right]
$$


where the element on the diagonal are spectral density functions of $(1-L) I_{t}$ and $(1-L) S_{t}$, while the off diagonal elements are the cross spectral density function of $(1-L) I_{t}$ and $(1-L) S_{t}$ respectively [43] [44].

To compute the spectral and cross spectral density function. Levy compute the autovariance and cross covariance function and then apply Fourier transformation to the resulting series.

Following Equation (4) above, $(1-L) I_{t}=z_{t}+(1-L) I_{t}$, with the autocovariance function

$$
\begin{aligned}
\gamma_{\Delta I}(\tau) & =E\left[\left(z_{t+\tau}+\Delta i_{t+\tau}\right)\left(z_{t}+\Delta i_{t}\right)\right] \\
& =E\left(z_{t+\tau} z_{t}\right)+E\left(\Delta i_{t+\tau} \Delta i_{t}\right)+E\left(z_{t+\tau}+\Delta i_{t}\right)+E\left(\Delta i_{t+\tau} z_{t}\right) \\
& =\gamma_{z}(\tau)+\gamma_{\Delta i}(\tau)+\gamma_{\Delta i, z}(\tau)
\end{aligned}
$$

Applying Fourier transform to both sides of Equation (6), we have:

$$
\begin{aligned}
& \frac{1}{2 \pi} \int_{-\infty}^{\infty} \gamma_{\Delta I}(\tau) \mathrm{e}^{-i \tau \omega} \mathrm{d} \tau \\
& =\frac{1}{2 \pi} \int_{-\infty}^{\infty} \gamma_{z}(\tau) \mathrm{e}^{-i \tau \omega} \mathrm{d} \tau+\frac{1}{2 \pi} \int_{-\infty}^{\infty} \gamma_{\Delta i}(\tau) \mathrm{e}^{-i \tau \omega} \mathrm{d} \tau \\
& \quad+\frac{1}{2 \pi} \int_{-\infty}^{\infty} \gamma_{z, \Delta i}(\tau) \mathrm{e}^{-i \tau \omega} \mathrm{d} \tau+\frac{1}{2 \pi} \int_{-\infty}^{\infty} \gamma_{\Delta i, z}(\tau) \mathrm{e}^{-i \tau \omega} \mathrm{d} \tau
\end{aligned}
$$

Using the standard definitions of spectral and cross spectral density functions presented by Levy [43], we have

$$
f_{\Delta I}(\omega)=f_{z}(\omega)+f_{\Delta i}(\omega)+f_{z, \Delta i}(\omega)+f_{\Delta i, z}(\omega) .
$$

Realizing that the $f(\omega)$ is a complex function, apply Cartesian form, written as:

$$
\begin{aligned}
& f_{z, \Delta i}(\omega)=C_{z, \Delta t}(\omega)-i q_{z, \Delta i}(\omega) . \\
& f_{\Delta i, z}(\omega)=C_{\Delta t, z}(\omega)-i q_{\Delta i, z}(\omega) .
\end{aligned}
$$

where $c$ denotes the cospectral density function and $q$ denotes the quadrature spectral function. Following the derivation results presented by Priestley [45],

$$
f_{z, \Delta i}(\omega)=\overline{f_{\Delta i, z}(\omega)}
$$

where bar denote complex conjugate. Thus, using Equation (9), we have:

$$
f_{z, \Delta i}(\omega)+f_{\Delta i, z}(\omega)=f_{z, \Delta i}(\omega)+\overline{f_{z, \Delta i}(\omega)}=2 c_{z, \Delta i}(\omega) .
$$

Therefore, Equation (8) can be rewritten as:

$$
f_{\Delta I}(\omega)=f_{z}(\omega)+f_{\Delta i}(\omega)+2 c_{z, \Delta i}(\omega) .
$$

Similarly, deviation of $f_{\Delta s}(\omega)$ and $f_{\Delta I, \Delta S}(\omega)$ is express as:

$$
\begin{gathered}
f_{\Delta s}(\omega)=f_{z}(\omega)+f_{\Delta s}(\omega)+2 c_{z, \Delta s}(\omega) \\
f_{\Delta I, \Delta S}(\omega)=f_{z}(\omega)+f_{\Delta i, \Delta s}(\omega)+f_{z, \Delta s}(\omega)+f_{\Delta i, z}(\omega)
\end{gathered}
$$

Since $z_{t}$ is an error term/white noise process, it sis theoretical band is flat equals $f_{z}(\omega)=\sigma^{2} / 2 \pi$ for all frequencies $-\pi \leq \omega \leq \pi$. In addition, $\Delta i$ and, $\Delta s$ are, $I(-1)$ and therefore their frequency cospectral density, Cospectral 
density function equal zero.

Thus, combining Equations (12) and (14), the spectral matrix in Equation (5) evaluated at zero frequency becomes:

$$
\left.f(\omega)\right|_{\omega=0}=\left[\begin{array}{ll}
\frac{\sigma_{z}^{2}}{2 \pi} & \frac{\sigma_{z}^{2}}{2 \pi} \\
\frac{\sigma_{z}^{2}}{2 \pi} & \frac{\sigma_{z}^{2}}{2 \pi}
\end{array}\right] .
$$

From the polar representation of $f(\omega)$ we have

$$
R_{y, x}^{2}(\omega)=\frac{\left|f_{x, y}(\omega)\right|^{2}}{f_{y}(\omega) f_{x}(\omega)}=\frac{c_{y, x}^{2}(\omega)+q_{y, x}^{2}(\omega)}{f_{y}(\omega) f_{x}(\omega)}
$$

and

$$
\Gamma_{y, x}(\omega)=\frac{\left|f_{y, x}(\omega)\right|}{f_{y}(\omega)}=\frac{\left|c_{y, x}^{2+}(\omega)+q_{y, x}^{2}(\omega)\right|^{1 / 2}}{f_{y}(\omega)}
$$

where $R_{y, x}^{2}(\omega)$ and $\Gamma_{y, x}(\omega)$ denote the squared coherence and the gain of investment and saving, respectively (see Jenkin \& Watts, 1968). Thus, using matrix in Equation (15) along with definition of squared coherence and gain provided in Equations (16) and (17), we show the zero frequency as

$$
\left.R_{y, x}^{2}(\omega)\right|_{\omega=0}=\frac{\left|\frac{\sigma_{z}^{2}}{2 \pi}\right|^{2}}{\frac{\sigma_{z}^{2}}{2 \pi} \frac{\sigma_{z}^{2}}{2 \pi}}=1
$$

\subsection{Model Building Block}

This study draws inspiration from the Keynesian theory of savings and investment as used by Feldtein and Horioka [38]. In particular, Felstein and Horioka combined the absolute income hypothesis and the life cycle hypothesis in developing their theoretical framework. The model is specified as:

$$
\left|\frac{I}{Y}\right|_{t}=\alpha+\beta\left|\frac{S}{Y}\right|_{t}+\mu_{t}
$$

where $I$ denote domestic investment, $S$ denote national savings, $Y$ denote income and $\mu_{t}$ denote error term. The coefficient $\alpha$ referred to as saving retention coefficient measured as the proportion of the incremental saving that is invest in the domestic economy.

Two major hypotheses are in support of this framework. First, the absolute income hypothesis postulated by Keynes [24] established the link between savings and income. Keynes suggested that savings is a function of income but the relationship is not linear as represented above.

Thus our model becomes:

$$
I N V_{t}=\alpha+\beta_{1} S A V_{t}+\beta_{2} C F_{t}+\beta_{3} L M_{t}+\beta_{4} F E D_{t}+\mu_{t}
$$

where, $I N V_{t}$ is the ratio of non-government gross investment to GDP (the true 
rate aggregate business investment) in year $t, S A V_{t}$ ratio of national savings to GDP (domestic savings) in year $t, C F_{t}$ is proxy as the net capital flow as a percentage of GDP in year $t$ (external finance); LM is share of broad money in GDP (level of monetization in the economy) in year $t$; Financial development and efficiency proxy as the credit to the private sector as a ratio of banks overhead cost to total asset in year $t ; \alpha$ is constant; $\beta_{1-4}$ are slopes, $\mu_{t}$ error term and $t$ is time (Table 1).

\subsection{Econometric Techniques}

\section{1) Unit Root Test}

The Dickey Fuller (DF)-GLS unit root test was adopted in this study to test the stationarity of each of the variables [49]. The null hypothesis was that the variable was non stationary. If the values of the DF-GLS statistic was less than or equal to the critical value, then the null hypothesis was rejected and it can be inferred that the variable was stationary at conventional level. The expression for the unit root is given as follows.

$$
\Delta Y_{t}=\beta+\rho Y_{t-1}+\sum_{j=1}^{n} b_{j} \Delta Y_{t-s}+v_{t}
$$

It is important to include the lags of the dependent variable in Equation (1) to eliminate autocorrelation. The hypothesis for stationarity and non-stationarity are expressed in terms of $p$. When $\rho=0$, it implies that series is not stationary, hence it has unit root.

2) ARDL Bounds Cointegration Test

The study employs the Autoregressive Distributed Lag (ARDL) bounds test by Pesaran, Shin and Smith [50] to examine the effects of monetary policy on output growth in the long and the short run periods in Nigeria. With this approach,

Table 1. Present the expected signs of the independent variables.

\begin{tabular}{|c|c|c|c|c|}
\hline Variable & Theoretical Basis & $\begin{array}{l}\text { Expected } \\
\text { signs }\end{array}$ & Symbols & Data Source \\
\hline $\begin{array}{l}\text { Aggregate } \\
\text { Business } \\
\text { Investment }\end{array}$ & $\begin{array}{c}\text { Dobrinsky [46]; } \\
\text { Verma [36] }\end{array}$ & no sign & $\left(I N V_{t}\right)$ & $\begin{array}{l}\text { World Development Indicator, } \\
\text { 2017; CBN Statistical Bulletin, } \\
2017 \text { [47] [48] }\end{array}$ \\
\hline Nation savings & $\begin{array}{c}\text { Dobrinsky [46]; } \\
\text { Verma [36] }\end{array}$ & + & $\left(S A V_{t}\right)$ & $\begin{array}{c}\text { World Development Indicator, } \\
\text { 2017; CBN Statistical Bulletin, } \\
2017 \text { [47] [48] }\end{array}$ \\
\hline Capital flow & Dobrinsky [46] & \pm & $\left(C F_{t}\right)$ & $\begin{array}{l}\text { World Development Indicator } \\
\text { (WDI), 2017; CBN Statistical } \\
\text { Bulletin, 2017 [47] [48] }\end{array}$ \\
\hline $\begin{array}{c}\text { Level of } \\
\text { monetization }\end{array}$ & $\begin{array}{c}\text { Feldstein and } \\
\text { Horioka [38]; } \\
\text { Kaya [37] }\end{array}$ & \pm & $\left(L M_{t}\right)$ & $\begin{array}{l}\text { World Development Indicator, } \\
\text { 2017; CBN Statistical Bulletin, } \\
2017 \text { [47] [48] }\end{array}$ \\
\hline $\begin{array}{c}\text { Financial } \\
\text { Development } \\
\text { Efficiency }\end{array}$ & $\begin{array}{c}\text { Feldstein and } \\
\text { Horioka [38]; } \\
\text { Dobrinsky [46]; } \\
\text { Verma [36] }\end{array}$ & + & $\left(F E D_{t}\right)$ & $\begin{array}{l}\text { World Development Indicator, } \\
\text { 2017; CBN Statistical Bulletin, } \\
2017 \text { [47] [48] }\end{array}$ \\
\hline
\end{tabular}

Source: Authors computation. 
output growth is expressed as a function of the lagged value of itself and the current and the lagged values of the explanatory variables.

$$
\begin{aligned}
\Delta I N V_{t}= & a+\sum_{p=1}^{n} b_{p} \Delta I N V_{t-p}+\sum_{p=1}^{n} c_{p} S A V_{t-p}+\sum_{p=1}^{n} d_{p} C F_{t-p} \\
& +\sum_{p=1}^{n} e_{p} L M_{t-p}+\sum_{p=1}^{n} f_{p} F E D_{t-p}+\rho_{1} S A V_{t}+\rho_{2} C F_{t} \\
& +\rho_{3} L M_{t}+\rho_{4} F E D_{t}+e_{t}
\end{aligned}
$$

where $\Delta$ is the first difference operator. The parameters $\rho_{i}$, where $i=1,2,3$, $4,5,6,7$ are the respective long run multipliers while the parameters $b, c, d, e, f$, $g, h$ are the short run dynamic coefficients of the underlying ARDL model in the equation. $\varepsilon_{t}$ denotes the white noise error term. The Bounds cointegration test will involve estimating Equation (19) and restricting the parameters of the lag level variables to zero. Based on this equation, we tested the following null and alternative hypotheses:

$H_{0}=\rho_{1}=\rho_{2}=\rho_{3}=\rho_{4}=\rho_{5}=0$ (i.e. no cointegration or level relationship) as against $H_{1}=\rho_{1}=\rho_{2}=\rho_{3}=\rho_{4}=\rho_{5} \neq 0$.

The existence of co-integrating relationship among the variables is determined by testing the significance of the lag levels of the variables using the F-test. The calculated F-statistic is compared with the two critical values for the upper and lower bounds tabulated by Narayan [51].

3) Causality Test

Granger [52] proposed a time series procedure in order to determine causality among time series variables. In Granger sense, there are three possible situations in which a Granger-causality test can be applied. First, in a simple Granger Causality there are two variables and lag considered; second is a multivariate Granger Causality test were more than two variables are considered, while the third considered testing a VAR framework. In this present study the multivariate Granger Causality is used.

Owing to the fact that the direction of co-integration is not a priori established, then each variable is normalized as dependent variable while the existence of level relationship is tested. We study also conducted diagnostic tests such as serial correlation, normality, functional form and heteroscedasticity tests.

\section{Econometric Analysis}

\subsection{Unit Roots Test}

Prior to our cointegration tests, it is conventionally plausible to first carry out unit root test to probe the order of cointegration of the series data. The rationale behind the unit root test lies in the fact that the tests help to determine the nature of the series to avoid spurious regression results.

The unit roots estimates were based on Dickey Fuller-GLS test with the result presented in Table 2. From the table, it was observed that all the variables were $\mathrm{I}(1)$ and $\mathrm{I}(0)$ series. 
Table 2. Pre-test: DF-GLS unit root test.

\begin{tabular}{cccccccc}
\hline \multirow{2}{*}{ Variables } & \multicolumn{2}{c}{ Levels } & \multicolumn{4}{c}{ First Difference } & \multirow{2}{*}{$\begin{array}{c}\text { Order of } \\
\text { Integration }\end{array}$} \\
\cline { 2 - 7 } & ADF Test Stat. & $\mathbf{1} \%$ & $\mathbf{5 \%}$ & ADF Test Stat. & $\mathbf{1 \%}$ & $\mathbf{5 \%}$ & $\mathrm{I}(1)$ \\
\hline$\left(I N V_{t}\right)$ & $-4.58^{*}$ & -3.62 & -2.94 & $-7.80^{*}$ & -3.63 & -2.94 & $\mathrm{I}$ \\
$\left(S A V_{t}\right)$ & -1.34 & -3.62 & -2.94 & $-4.37^{*}$ & -3.63 & -2.94 & $\mathrm{I}(1)$ \\
$\left(C F_{t}\right)$ & -1.88 & -3.62 & -2.94 & $-6.98^{*}$ & -3.62 & -2.94 & $\mathrm{I}(1)$ \\
$\left(L M_{t}\right)$ & -1.18 & -3.62 & -2.94 & $-12.01^{*}$ & -3.63 & -2.94 & $\mathrm{I}(1)$ \\
$\left(F E D_{t}\right)$ & -2.08 & -3.62 & -2.94 & -3.78 & -3.62 & -2.94 & $\mathrm{I}(1)$ \\
\hline
\end{tabular}

${ }^{*}$ indicate $1 \%$, ${ }^{*}$ indicate $5 \%$, level of significance. Source: Authors' computation.

\subsection{ARDL Cointegration Results}

In order to empirically examine the long-run nexus and short-run dynamic relationships among our research variables, we explore the ARDL bounds test co-integration method developed by Pesaran and Shin [50]. Our choice of method was necessitated by the fact that the method is more explicit and reliable in probing the extent of the relationship among variables in comparison with other previous and traditional co-integration methods. Specifically, the ARDL is not preconditioned to the uniformity of co-integration order for all variables. In essence, the need for all the variables to be integrated in the same order and it can equally be applied when variables are either integrated at level or first difference. More importantly, Harris and Sollis [53], noted that applying the ARDL technique enhance unbiased estimates of the long-run model.

Going by the underlining assumptions of the ARDL Model, one set assumes that all variables in the model are $I(0)$ and the other set assumes they are all $I(1)$. If the calculated F-statistic exceeds the upper critical bounds value, then the $\mathrm{H}_{0}$ is rejected. If the F-statistic falls within the bounds, then the test is inconclusive. Lastly, if the F-statistic falls below the lower critical bounds value, it implies that there is no co-integration.

Hence, from the ARDL Bound Test co-integration results, the value of the F-static (12.51) exceeds the critical values at the upper bound (44.68 at 1\%, 4.18 at $2.5 \%, 3.79$ at $5 \%$ and 3.35 at $10 \%$ ). Therefore, the empirical findings lead to the conclusion that a long run relationship exists among business investment $\left(I N V_{t}\right)$, national saving $\left(S A V_{t}\right)$, Capital flow $\left(C F_{t}\right)$, Level of monetization $\left(L M_{t}\right)$ and Financial development efficiency $\left(F E D_{t}\right)$.

\subsection{Long Run Coefficients Estimates Using ARDL Approach}

Having established the existence of co-integration from Table 3, the conditional ARDL for the long run relationship can be estimated given the model as thus;

$$
\begin{aligned}
\ln I N V_{t}= & a+\sum_{p=1}^{n} b_{p} \ln \left(I N V_{t-p}\right)+\sum_{p=1}^{n} c_{p} \ln \left(S A V_{t-p}\right)+\sum_{p=1}^{n} d_{p} \ln \left(C F_{t-p}\right) \\
& +\sum_{p=1}^{n} e_{p} \ln \left(L M_{t-p}\right)+\sum_{p=1}^{n} f_{p} \ln \left(F E D_{t-p}\right)+e_{t}
\end{aligned}
$$


Table 3. Estimated bound test results.

\begin{tabular}{cccccc}
\hline \multirow{2}{*}{ Test Statistic } & \multirow{2}{*}{ Value } & \multirow{2}{*}{} & \multicolumn{3}{c}{ Critical Value Bounds } \\
\cline { 4 - 6 } & & & Significance & $\mathrm{I}(0)$ & $\mathrm{I}(1)$ \\
\hline \multirow{2}{*}{ F-Statistic } & \multirow{2}{*}{5.51} & & $10 \%$ & 2.26 & 3.35 \\
& & & $5 \%$ & 2.62 & 3.79 \\
& & $2.5 \%$ & 2.96 & 4.18 \\
& & $1 \%$ & 3.41 & 4.68 \\
\hline
\end{tabular}

Source: Authors' computation.

where, all variables are as previously defined. The order of the ARDL $\left(p, q_{1}, q_{2}, q_{3}, q_{4}, q_{5}\right)$ model in five variables are selected by using AIC Equation (21) is estimated using the ARDL $(1,0,0,0,0)$ specification (Table 4).

From the long run estimates results in Table 4, it was observably shown that except for negative relations in Capital flow $\left(C F_{t}\right)$, other variables are significant enough to explain business investment in Nigeria and all conform to theoretical expectation. Thus, null hypothesis of no significant relation between and independent variables are rejected. Specifically, $1 \%$ point increase in national saving $\left(S A V_{t}\right)$, Level of monetization $\left(L M_{t}\right)$ and Financial development efficiency $\left(F E D_{t}\right)$ increase business investment by $0.04,0.2,0.49$ respectively. However, Capital flow $\left(C F_{t}\right)$ suggested a negative impact on business investment in Nigeria which conform to a prior expectation. Thus, an increase in capital flow $\left(C F_{t}\right)$ by $1 \%$, business investment $\left(I N V_{t}\right)$ is expected to reduce by $0.2 \%$ correspondingly.

\subsection{Short Run Estimates Using ARDL Approach}

Taking inferences from the studies conducted by Odhiambo [54] and Narayan, Smyth [55] and Mounir (n.d.) [56], we further estimate the short-run parameters through the error correction model in relation to the long-run parameters estimates. The stated hypothesis of no co-integration which is associated with the vector error correction model is stated thus:

$$
\begin{aligned}
\ln \left(\Delta I N V_{t}\right)= & a+\sum_{p=1}^{n} b_{p} \ln \left(\Delta I N V_{t-p}\right)+\sum_{p=1}^{n} c_{p} \ln \left(\Delta S A V_{t-p}\right)+\sum_{p=1}^{n} d_{p} \ln \left(\Delta C F_{t-p}\right) \\
& +\sum_{p=1}^{n} e_{p} \ln \left(\Delta L M_{t-p}\right)+\sum_{p=1}^{n} f_{p} \ln \left(\Delta F E D_{t-p}\right)+\alpha E C T_{t-1}+e_{t}
\end{aligned}
$$

where, all variables are as previously defined. The order of the ARDL

$\left(p, q_{1}, q_{2}, q_{3}, q_{4}, q_{5}\right)$ model in five variables are selected by using AIC Equation (22) is estimated using the $\operatorname{ARDL}(3,2,1,2,3)$ specification.

The short run dynamic relationship between saving and investment fundamentals in Nigeria is indicated in the second part of the estimated ARDL in Table 4. The estimated short run results suggested that first and second (lagged) of national saving $\left(S A V_{t}\right)$ exert positively on business investment $\left(I N V_{t}\right)$ in Nigeria. The results show that error correction term (ECT) was statistically significant 
Table 4. Estimated autoregressive distributive lag (ARDL) results.

\begin{tabular}{|c|c|c|c|c|c|}
\hline & Variable & Coefficient & Std Error & t-statistic & Prob \\
\hline & $S A V_{t}(-1)$ & 0.04 & 0.01 & 2.33 & 0.06 \\
\hline & $C F_{t}(-1)$ & -0.12 & 0.05 & -2.39 & 0.06 \\
\hline & $L M_{t}(-1)$ & 0.23 & 0.04 & 4.81 & 0.00 \\
\hline & $F E D_{t}(-1)$ & 0.49 & 0.06 & 7.52 & 0.01 \\
\hline & $C$ & 2.86 & 4.75 & -0.60 & 0.57 \\
\hline & $D\left(I N V_{t}(-1)\right)$ & $0.60^{*}$ & 0.13 & -4.36 & 0.01 \\
\hline & $D\left(I N V_{t}(-2)\right)$ & $0.72^{*}$ & 0.12 & -7.46 & 0.02 \\
\hline & $D\left(I N V_{t}(-3)\right)$ & $-0.86^{*}$ & 0.09 & -3.71 & 0.01 \\
\hline & $D\left(S A V_{t}\right)$ & -0.01 & 0.04 & -0.30 & 0.77 \\
\hline & $D\left(S A V_{t}(-1)\right)$ & $0.09^{*}$ & 0.04 & 2.23 & 0.07 \\
\hline & $D\left(S A V_{t}(-2)\right)$ & $0.07^{*}$ & 0.04 & 4.79 & 0.03 \\
\hline & $D\left(C F_{t}\right)$ & $-0.06^{*}$ & 0.01 & -3.45 & 0.01 \\
\hline \multirow{9}{*}{$\begin{array}{l}\text { Short-run } \\
\text { Equation }\end{array}$} & $D\left(C F_{t}(-1)\right)$ & $0.13^{*}$ & 0.05 & 2.42 & 0.06 \\
\hline & $D\left(L M_{t}\right)$ & -0.01 & 0.05 & -0.25 & 0.81 \\
\hline & $D\left(L M_{t}(-1)\right)$ & 0.26 & 0.22 & 1.19 & 0.28 \\
\hline & $D\left(L M_{t}(-2)\right)$ & -0.06 & 0.10 & -0.64 & 0.54 \\
\hline & $F E D_{t}$ & 0.08 & 0.07 & 1.10 & 0.31 \\
\hline & $D\left(F E D_{t}(-1)\right)$ & $-0.42^{\star}$ & 0.04 & -8.86 & 0.00 \\
\hline & $D\left(F E D_{t}(-2)\right)$ & 0.08 & 0.10 & 0.83 & 0.44 \\
\hline & $D\left(F E D_{t}(-3)\right)$ & $0.03^{*}$ & 0.01 & 1.95 & 0.10 \\
\hline & $F E D_{t} E C M(-1)$ & $-0.34^{*}$ & -0.09 & -1.14 & -0.02 \\
\hline
\end{tabular}

$\left.\left(^{*}\right)^{(*}\right)\left({ }^{* * *}\right)$ indicate $1 \%, 5 \%, 10 \%$ level of significant. Source: Authors' computation.

with negative sign as expected. Explicitly, the coefficient of the lagged error correction term (ECT) is (0.34) and negatively significant at $1 \%$. The magnitude of the coefficient implies that $34 \%$ of the disequilibrium caused by previous shocks converges back to the long run equilibrium in the current period.

\subsection{Granger Causality Tests}

Causality is a critical issue when testing co-integration and in general macroeconomic model building. Below is the Pairwise Granger causality test that determines the cause effects of the Savings-Investment fundamentals. The results are analysed based on their causal direction. In econometric analysis, unidirec- 
tional Granger Causality is usually used to predict the possibility of a variable to influence another without possibility of reversed case. Bidirectional or feedback causality of the growth rate of variables has the possibility of predicting each other, while no direction or independence between two or more variables show no Granger causality [27].

The pairwise Granger causality test presented aims to determine whether causality exist between savings and investment fundamentals. Precisely, Table 5 affirmed that bidirectional relationship exists between national savings $\left(S A V_{t}\right)$ and business investment ( $\left.I N V_{t}\right)$, which implies that domestic resource mobilization through savings can trigger business investment in Nigeria and as well business investment $\left(I N V_{t}\right)$ can enhance national savings $\left(S A V_{t}\right)$ respectively. Similarly, bidirectional link exists between capital flow $\left(C F_{t}\right)$ and business investment $\left(I N V_{t}\right)$. Interestingly, unidirectional relationship is observed between Level of monetization $\left(L M_{t}\right)$ and Financial development efficiency $\left(F E D_{t}\right)$ and business investment $\left(I N V_{t}\right)$, which suggests that the variables in the model can trigger and propel business investment during the period reviewed.

\subsection{Post Test: Residual Diagnostic Tests Results}

The estimated ARDL was tested for heteroscedasticity, serial correlation, function form misspecification, parameter stability and normality. The results from the test are shown in Table 6.

The model for the underlying ARDL fulfills the stated criteria examined by all the diagnostic tests observable from the serial correlation (Durbin Watson test and Breusch-Godfrey test) which suggests that the model is free from serial correlation. This indicates that the model is reliable in explaining the dynamics of

Table 5. Summary of pairwise granger causality test.

\begin{tabular}{ccc}
\hline Bidirectional & Unidirectional & No Causality \\
\hline$S A V \leftrightarrow I N V$ & $F E D \rightarrow I N V$ & $L M-S A V$ \\
$C F \leftrightarrow I N V$ & $L M \rightarrow I N V$ & $F E D-S A V$ \\
\hline
\end{tabular}

Source: Authors computation.

Table 6. Residual diagnostic tests results of ARDL.

\begin{tabular}{ccc}
\hline & F-Statistic & Probability \\
\hline Breusch-Godfrey Serial Correlation test & 2.35 & 0.10 \\
Jarque-Bera test & 0.93 & 0.56 \\
Wald Test & $31.51^{\star * *}$ & 0.00 \\
Breusch-Pagan-Godfrey Heteroskedasticity Test & 0.88 & 0.72 \\
Ramsey RESET Test & 0.03 & 0.97 \\
Chow Forecast Test (Likelihood ratio) & $65.66^{\star * *}$ & 0.00 \\
\hline
\end{tabular}

Note: ${ }^{*}{ }^{* *}$ and ${ }^{* * *}$ signify significant level at $1 \%, 5 \%$ and $10 \%$ respectively. Source: Authors' computation. 
inflation in Nigeria for the study period. Similarly, the Breusch-Pagan-Godfrey Heteroskedasticity test reveals that the disturbance term in the equation is equally homoscedastic. Going by the result of the Jarque-Bera (JB) test, the null hypothesis of normally distributed residuals cannot be rejected. While the Ramsey RESET test result shows that there is no specification error, the Wald test reinforces our standpoint about the validity and correctness of our obtained results. Finally, the Chow predictive failure test suggests that the model may possibly be useful for forecasting with 2009 as the breakpoint year.

\section{Concluding Remarks}

Despite the significant level of resource endowments, savings mobilization remains a puzzle to business investment in Nigeria. This paper therefore revalidates the potential of domestic resource mobilization as it affects business investment in Nigeria between 1981 and 2017. The ARDL Bound test approach was employed to check the interaction and feedback mechanism between savings and investment fundamentals.

The empirical results have confirmed the strong positive correlation between national savings and investment suggesting that policies/initiatives to increasing the domestic resource mobilization through national savings are crucial for stimulating rate of investment in Nigeria. This therefore suggests that policy priority should be centered on awareness of financial inclusion by banking the unbanked as well as encouraging existing banking population. Also, the need to curtail savings export to encourage investment opportunities should be given serious policy attention as this is likely to have serious implication on future growth of the country.

Further analysis indicated that financing constraints are major determinants of investment decision in Nigeria. The negative relationship between investment and financial development shows that such financial constraints may arise from scarce domestic financial resource or financial market imperfection. Therefore, the study suggests that eliminating this constraint through restructuring of the financial markets to spur investment is crucial for future growth of the country. Beyond obvious the result has clearly shown a warning sign that the present state of the Nigerian Financial Market cannot stimulate investment. Therefore, the efficiency of the financial system emerges as the key factor to act as a channel of moving resources from the surplus unit to the deficit sector giving priority to the real drivers of the economy.

\section{Conflicts of Interest}

The authors declare no conflicts of interest regarding the publication of this paper.

\section{References}

[1] Harrod, R. (1939) An Essay in Dynamic Theory. Economic Journal, 49, 14-33. https://doi.org/10.2307/2225181 
[2] Lewis, W.A. (1955) Theory of Economic Growth. Allen and Unwin Ltd, London.

[3] Solow. R (1956) A Contribution to the Theory of Economic Growth. The Quarterly Journal of Economics, 70, 65-94. https://doi.org/10.2307/1884513

[4] Swam, T.W. (1956) Economic and Capital Accumulation. Economic Record, 32, 334-361. https://doi.org/10.1111/j.1475-4932.1956.tb00434.x

[5] Domar, E.D. (1946) Capital Expansion, Rate of Growth and Employment. Econometrica, 14, 137-147. https://doi.org/10.2307/1905364

[6] Tobin, J. (1983) Domestic Saving and International Capital Movements in the Long Run and Short Long by M. Feldstein: Comment. European Economic Review, 2, 425-444. https://doi.org/10.1016/S0014-2921(83)80013-0

[7] Lucas, R.E. (1988) On the Mechanics of Economic Development. Journal of Monetary Economics, 22, 3-42. https://doi.org/10.1016/0304-3932(88)90168-7

[8] Mankiw, G., Romer, D. and Weil, D. (1992) A Contribution to the Empirics of Economic Growth. Quarterly Journal of Economics, 107, 407-437. https://doi.org/10.2307/2118477

[9] Feldstein, M. (1983) Domestic Savings and International Capital Movement in the Long Run and the Short Run. European Economic Review, 2, 129-151. https://doi.org/10.1016/S0014-2921(83)80012-9

[10] Bayoumi, T. (1990) Saving-Investment Correlation: Immobile Capital, Government Policy, or Endogenous Behaviour? IMF Staff Papers, 37, 360-387. https://doi.org/10.2307/3867294

[11] Sinn, S. (1992) Saving-Investment Correlation and Capital Mobility: On the Evidence from Annual Data. The Economic Journal, 102, 1161-1170. https://doi.org/10.2307/2234383

[12] Tang, C.F. and Tan, B.W. (2014) A Revalidation of Saving-Growth Nexus in Pakistan. Economic Modelling, 36, 370-377. https://doi.org/10.1016/j.econmod.2013.10.012

[13] Smith, A. (1777) An Inquiry into the Nature and Causes of Wealth of a Nation. Chicago University Press, Chicago (1976).

[14] Ricardo, D. (1821) On the Principle of Political Economy and Taxation. 3rd Edition, Vol. (1).

[15] Say's, J.B. (1821) A Treatise on Political Economy. 4th Edition, Kelly, New York (1971), (1 $\left.1^{\text {st }} \mathrm{Ed}, 1803\right)$.

[16] Joplin, T. (1823) Outline of a System of Political Economy. Craddock and Joy, London.

[17] Mill, J.S. (1826) Essay on Some Unsettle Questions in Political Economy. Kelly, New York.

[18] Schumpeter (1939) Business Cycle. McGraw Hill, New York.

[19] Large, O. (1942) Say's: A Restatement and Criticism in Studies of Mathematical Economics and Econometrics in Memory of Henry Schuler. Chicago University Press, Chicago.

[20] Kaldor, N. (1955) Alternative Theories of Distribution. Review of Economic Studies, 23, 83-100. https://doi.org/10.2307/2296292

[21] Samuelson, P. (1971) Paradoxes of Schumpeter's Zero Interest Rate. Review of Economics and Statistics, 53, 391-392. https://doi.org/10.2307/1928744

[22] Baumol, T.W. (1977) Say's (at Least) Eight Law's or What Say and James Mill May Really Have Meant. Economica, 44, 145-162. 
[23] Adeleke, I.A., Uboh, V. and Shobande, O.A (2015) Monetary Policy toward Inclusive Growth in Nigeria. Journal of Social Science, 57, 80-114.

[24] Keynes, J.M. (1936) General Theory of Employment, Interest and Money. Macmillan, London.

[25] Mickinnon, R.I. (1973) Money and Capital in Economic Development. Brookings Institution, Washington DC.

[26] Shaw, E. (1973) Financial Deeping in Economic Development. Oxford University Press, New York.

[27] Shobande, O.A and Ibrahim, R. (2018) Modelling Dynamic of Inflation in Nigeria. Journal of Economic Library, 5, 229-240.

[28] Odey, F.I., Effiong, C.E. and Nwafor, J.U. (2017) Saving, Investment and Economic Growth Nexus in Nigeria. International Journal of Development and Economic Sustainability, 5, 1-14.

[29] Ajakaiye, O. and Babatunde, M.A. (2016) Monetary Policy Thrust for Inclusive Growth in Nigeria. Journal of Economics and Policy Analysis, 1, 14-30.

[30] Adeoye, W.B. and Shobande, O.A. (2016) Emergence of the New Monetary Policy Mandate and Macroeconomic Shock: A VAR Approach. Journal of Economic and Policy Analysis, 1, 47-56.

[31] Shobande, O.A., Ezenekwe, U.R. and Uzonwanne, M.C. (2018) Restructuring Rural Financial Market for Agricultural Growth in Nigeria. Turkish Economic Review, 5, 241-255.

[32] Shobande, O.A. (2018) Modelling the Dynamics of Government Finance on Bond Market Return in Nigeria. Theoretical Economics Letters, 8, 3438-3443. https://doi.org/10.4236/tel.2018.815210

[33] Nwokoma, N.I. (2004) Stock Market Performance and Macroeconomic Indicators Nexus in Nigeria: An Empirical Investigation. Nigerian Journal of Economic and Social Studies, 44, 12-110.

[34] Jagadesh, D. (2015) The Impact of Savings in Economic Growth. An Empirical Study Based on Botswana. International of Research in Business Studies and Management, 2, 10-21.

[35] Chakrabarti, A. (2006) The Saving-Investment Relationship Revisited: New Evidence from Multivariate Heterogonous Panel Cointegration Analyses. Journal of Comparative Economics, 34, 402-429. https://doi.org/10.1016/j.jce.2006.02.001

[36] Verma, R. (2007) Savings, Investment and Growth in India: An Application of the ARDL Bound Testing Approach. South Asia Economic Journal, 8, 87-98. https://doi.org/10.1177/139156140600800105

[37] Kaya, H. (2010) Saving and Investment Association in Turkey. Topic in Middle Eastern and African Economies, 12.

[38] Feldstein, M. and Horioka, C. (1980) Domestic Savings and International Capital Flows. The Economic Journal, 90, 314-329. https://doi.org/10.2307/2231790

[39] Tang, C.F. and Lean, H.H. (2008) The Savings and Investment Nexus: Evidence from the Rolling Window Bound Test. Asian Business and Economic Research Unit, Discussion Paper 66.

[40] Adebole, S.S. and Dahalan, J. (2012) Capital Mobility: Application of Saving-Investment Link in Tunisia. International Journal of Economics and Financial Issues, 21, 1-11.

[41] Nasiru, I. and Usman, H. (2013) The Relationship between Domestic Savings and Investment: The Feldstein-Horioka Test Using Nigeria Data. CBN Journal of Ap- 
plied Statistics, 4, 75-88.

[42] Ayatuoma, O.C. and Musilika, O.A. (2014) Investigating the Relationship between Aggregate Savings and Investment in Namibia: A Causality Analysis. Research Journal of Finance and Accounting, 5, 82-89.

[43] Levy, D. (2000) Investment-Saving Comovement and Capital Flow Mobility: Evidence from Long U.S. Time Series. Review of Economic Dynamics, 3, 100-136. https://doi.org/10.1006/redy.1999.0060

[44] Coakely, J., Kulasi, F. and Smith, R. (1996) Current Account Solvency and Feldstein Horioka Puzzle. Economic Journal, 106, 620-627. https://doi.org/10.2307/2235567

[45] Priestley, M.B. (1981) Spectral Analysis and Time Series. Academic Press, New York.

[46] Dobrinsky, R. (2005) Domestic Savings and the Driving Forces of Investment in the ECE Emerging Market. Discussion Paper Series, United Nation Economic Commission for Europe, Geneva.

[47] World Development Indicator (2017) World Bank Data, World Bank Group. http://data.worldbank.org/country/nigeria

[48] Central Bank of Nigeria (CBN) (2017) Statistical Bulletin, 2017. CBN.

[49] Dickey, D.A. and Fuller, W.A. (1981) Likelihood Ratio Statistics for Autoregressive Time Series with a Unit Root. Econometrica, 49, 1057-1072. https://doi.org/10.2307/1912517

[50] Pesaran, M.H., Shin, Y. and Smith, R.J. (2001) Bounds Testing Approaches to the Analysis of the Level Relationship. Journal of Applied Economics, 16, 289-326. https://doi.org/10.1002/jae.616

[51] Narayan, P.K. (2005) The Relationship between Saving and Investment for Japan. Japan and World Economy, 17, 239-309.

[52] Granger, C.W.J. and Hallman, J. (1964) Spectral Analysis of Economic Time Series. Princeton University Press, Princeton.

[53] Harris, R. and Sollis, R. (2003) Applied Time Series Modeling and Forecasting. Wiley, West Sussex.

[54] Odhiambo, N.M. (2009) Energy Consumption and Economic Growth in Tanzania: An ARDL Bounds Testing Approach. Energy Policy, 37, 617-622. https://doi.org/10.1016/j.enpol.2008.09.077

[55] Narayan, P.K. and Smyth, R. (2008) Energy Consumption and Real GDP in G7 Countries: New Evidence from Panel Cointegration with Structural Breaks. Energy Economics, 30, 2331-2341. https://doi.org/10.1016/j.eneco.2007.10.006

[56] Mounir, B. (n.d.) The Relationship between Trade, FDI and Economic Growth in Tunisia: An Application of the Autoregressive Distributed Lag Model. Faculty of Economics and Management of Sousse, University of Sousse City, Sousse Tunisia. 